ISSN. 2775-4324 (Online)

Journal of Physical Activity and Sports

Volume 2, Nomor 2, Agustus 2021, 243-247

Journal of Physical Activity and Sports

\title{
Analisis Pembelajaran Daring Siswa Sekolah Menengah Atas Di Kecamatan Mranggen Kelas Xi Ditengah Pandemi Covid-19
}

\author{
Jayanti Gustia Wulandari \\ Universitas PGRI Semarang, Jalan Sidodadi Timur No. 24 Dr. Cipto, Semarang, Indonesia \\ * Coressponding Author. Email: jayantigustia@gmail.com
}

Received: 29 Desember 2020; Revised: 24 Agustus 2021; Accepted: 31 Agustus 2021

\begin{abstract}
This research is motivated by the Covid-19 pandemic in Indonesia which has an impact on the economic inequality of society and also the impact of education which hinders the learning process. This has led to a new learning method called online learning or distance learning which is now being implemented by the government. Students are required to take online learning because the Covid-19 pandemic does not allow students to take face-to-face learning with the teacher. The purpose of this study to analyze online learning in Upper Middle School Students in Mranggen District.

The method used in this research is descriptive qualitative method. Test the validity of the data using validity and credibility tests. The data analysis used is reduction, display data, and conclusion drawing / verification.

The results of this study indicate that online learning or distance learning has many advantages and disadvantages experienced by students, parents, and physical education teachers in SMA Mranggen District. In its strength, students know more about information technology or what is called IT. The drawback of online learning itself is that the limited facilities and infrastructure that are owned by the teacher and students make learning less optimal. The conclusion of this research is that research can get results that the Covid-19 pandemic has advantages and disadvantages of online learning from Physical Education and Health in Mranggen District.
\end{abstract}

Keywords: Learning analysis, online learning, covid-19 pandemic.

\begin{abstract}
Abstrak
Penelitian ini dilatarbelakangi oleh pandemi covid-19 di Indonesia yang menimbulkan dampak dari kesenjangan ekonomi masyarakat dan juga dampak dari pendidikan yang menghambat proses pembelajaran. Hal ini yang menimbulkan metode pembelajaran baru yang disebut dengan pembelajaran daring atau pembelajaran jarak jauh yang kini diterapkan oleh pemerintah.Siswa wajib mengikuti pembelajaran secara daring dikarenakan pandemi covid-19 ini tidak memungkinkan siswa dalam mengikuti pembelajaran secara tatap muka dengan guru.Tujuan dari penelitian ini untuk menganalisis pembelajaran daring pada Siswa Menengah Atas di Kecamatan Mranggen. Metode yang digunakan dalam penelitian ini adalah metode kualitatif deskriptif.Uji keabsahan data menggunakan validitas dan uji kredibilitas. Analisis data yang digunakan yaitu reduction, data display, dan conclusion drawing/verification.

Hasil penelitian ini menunjukan bahwa pembelajaran daring atau pembelajaran jarak jauh memiliki banyak kelebihan dan kekurangan yang dialami pada siswa, orang tua siswa, dan guru penjas di SMA Kecamatan Mranggen. Pada kelebihannya siswa menjadi lebih tau tentang information technology atau yang disebut dengan IT. Kekurangan dari pembelajaran daring sendiri yaitu dengan keterbatasan sarana dan prasarana yang dimiliki bagi pihak guru maupun siswa menjadikannya pembelajaran kurang maksimal.

Simpulan dari penelitian ini adalah penelitian dapat memperoleh hasil bahwa pandemi covid-19 ini memiliki kekurangan dan kelebihan pembelajaran daring penjasorkes di Kecamatan Mranggen
\end{abstract}

Kata kunci : Analisis pembelajaran, pembelajaran daring, pandemi covid-19 


\section{PENDAHULUAN}

Pada saat ini, dunia dihebohkan dengan adanya virus yang mematikan dan dapat menyerang siapa saja.Virus corona atau covid-19 menjadi ancaman bagi semua orang dalam menjalankan kegiatan sehari-harinya tak terkecuali dalam bidang pendidikan. Di tengah menyebarnya ini pemerintah mengeluarkan peraturan kepada semua orang termasuk untuk menjaga jarak kepada semua orang termasuk guru dan teman-teman yang ada disekolah. Peraturan tersebut membuat Menteri Pendidikan memberi kebijakan agar semua sekolah atau kegiatan belajar mengajar yang bersifat mengumpulkan banyak orang harus dihindari dan akibatnya seluruh sekolah harus diliburkan sementara dan dialihkan belajar dirumah masing-masing dengan sistem dalam jaringan atau online. Guru telah berupaya untuk memberikan pengajaran kepada siswanya melalui sistem dalam jaringan dengan memanfaatkan beberapa alat komunikasi modern. (Ahsani, E. L. F. 2020:38)

Dunia pendidikan menghadapi permasalahan yang cukup kompleks pada saat pandemi adanya covid-19 ini pembelajaran daring dapat dijadikan solusi untuk pembelajaran jarak jauh antara murid dengan guru, atau yang disebut dengan pembelajaran dirumah. Guru biasanya akan memberikan tugas masing-masing kepada muridnya agar siswa dapat belajar dirumah. Pada bulan Maret pemerintah sudah menerapkan sistem belajar dirumah, mata pelajaran penjasorkes sendiri termasuk dalam kategori pembelajaran praktek disekolah. Pada saat pandemi yang sekarang merajalela di Indonesia, guru penjasorkes sangat sulit untuk mengajar para siswanya disekolah.

Menurut Syah (Herlina, H., \& Suherman, M. 2020: 2) Terdapat empat kendala yang dihadapi oleh dunia pendidikan dimasa pandemi covid yakni 1) penguasaan internet yang terbatas guru; 2) kurang memadainya sarana prasarana; 3) terbatasnya akses internet; 4) tidak siap dana pada kondisi darurat.

\section{METODE}

Penelitian ini merupakan penelitian Deskriptif dengan pendekatan Kualitatif. Subjek Penelitian yaitu Siswa, Orangtua siswa, dan guru penjas. Pengumpulan data menggunakan metode observasi, wawancara, dokumentasi, instrumen pengumpulan data menggunakan lembar wawancara melalui google form. Analisis data menggunakan metode yang dilakukan secara terus menerus dengan reduksi data, penyajian data dan penarik kesimpulan.

\section{HASIL DAN PEMBAHASAN}

\section{Siswa}

\section{a. Aspek Akademik Siswa}

Aspek akademik siswa pada pembelajaran daring memiliki kelebihan dan kekurangan. Kelebihannya : pembelajaran dapat dilakukan dimana saja, interaksi guru dan siswa lebih efisien, dapat membantu pekerjaan orangtua dirumah, membantu otak tetap berkembang dengan memanfaatkan 
teknologi informasi yang ada. Kekurangan : pemberian tugas terlalu banyak, tidak paham dengan materi yang dijelaskan guru, terkendala pada kuota internet yang mudah cepat habis pada saat mengikuti pembelajaran daring.

\section{b. Aspek Kepribadian Siswa}

Selama pandemi covid-19 siswa menerapkan nilai-nilai positif yang ada disekolah contohnya : berolahraga, membantu orangtua membersihkan rumah, dan mentaati anjuran pemerintah dengan tetap mematuhi protokol kesehatan.

\section{c. Aspek Sosial Siswa}

Berdasarkan hasil penelitian, pandemi covid-19 ini mempengaruhi pemasukan siswa. Sebelum adanya pandemi siswa masih mendapatkan uang saku dari orangtuanya, dan sesudah adanya pandemi rata-rata siswa tidak mendapatkan uang saku dari orangtuanya. Sedangkan siswa butuh pengeluaran dalam membeli paket data untuk tetap mengikuti pembelajaran secara online.

\section{Orangtua Siswa}

\section{a. Aspek Ekonomi}

Berdasarkan hasil penelitian dari orang tua siswa, perekonomian orang tua siswa selama sebelum adanya pandemi masih stabil dikarenakan uang masih cukup untuk memenuhi kebutuhan keluarga serta masih memiliki penghasilan yang tetap. Perekonomian orang tua siswa setelah adanya pandemi ada yang memiliki penurunan karena covid-19 sangat merugikan perekonomian keluarga dan ada beberapa orang tua siswa mengalami PHK dari perusahaan.

\section{b. Tanggapan Terhadap Pembelajaran Daring Disekolah}

Orang tua siswa mengetahui bahwa sekolah menerapkan sistem pembelajaran jarak jauh atau yang disebut dengan pembelajaran daring, dan orang tua siswa mengetahui perkembangan pembelajaran anak selama pandemi karena orang tua mendampingi siswa disetiap proses pembelajaran jarak jauh dan guru memberikan hasil dari proses pembelajaran secara langsung.

Menurut orang tua siswa manfaat dari pembelajaan daring bagi siswa dapat menjaga jarak dan mengurai kerumunan. Anak dapat membagi waktu dengan membantu orang tua dan mengerjakan tugas sekolah.Anak lebih banyak waktu dengan keluarga dan pembelajaran lebih santai.

Kendala yang sering dialami siswa dalam pembelajaran daring menurut orang tua adalah paket data internet yang tidak memadahi, jaringan yang tidak stabil yang membuat pembelajaran menjadi terhambat, dan tidak semua anggota keluarga dapat membantu untuk memahami materi yang diajarkan. 


\section{Guru Penjas}

\section{a. Komunikatif}

Bagi guru penjas pembelajaran daring memiliki kelebihan dan kekurangan. Kelebihan : Menjadi lebih tau information technology atau yang disebut dengan IT, dapat menyingkat waktu pembelajaran, dan proses belajar mengajar dapat berlangsung dimanapun selama kondusif dan dapat membantu untuk fokus pada siswa. Kekurangan : kurangnya komunikasi antara guru dengan siswa, terkendala pada sinyal, dan kuota yang boros.

\section{b. Profesional guru penjas}

Pembelajaran daring merupakan metode pembelajaran baru bagi guru. Guru beranggapan pembelajaran daring kini yang diterapkan efektif jika siswa dan guru dapat sama-sama menerapkannya namun, pada kenyataannya banyak faktor yang menyebabkan pembelajaran daring sulit diterapkan. Respon guru pada saat siswa sering mengalami kendala dalam mengikuti pembelajaran jarak jauh yaitu mengingatkan dan memotivasi siswa serta memberikan pengertian lebih detail tentang materi yang dipelajari saat itu

\section{c. Pengetahuan}

Guru memiliki strategi mengajar yang diberikan kepada siswa agar tidak mudah bosan saat pembelajaran daring.Memberikan video yang menarik serta berhubungan dengan materi yang membuat semangat belajar siswa dalam mengikuti pembelajaran daring.Video ini memiliki maksud agar pembelajaran tidak monoton dan mampu dipahami oleh siswa.Pembelajaran daring tidak berbeda dengan pembelajaran tatap muka dalam segi tujuan pembelajaran.

\section{KESIMPULAN}

Hal ini dapat disimpulkan bahwa pembelajaran daring atau pembelajaran jarak jauh memiliki banyak kelebihan dan kekurangan yang dialami pada siswa, orang tua siswa, dan guru penjas di SMA Kecamatan Mranggen. Pada kelebihannya siswa menjadi lebih tau tentang information technology atau yang disebut dengan IT. Kekurangan dari pembelajaran daring sendiri yaitu dengan keterbatasan sarana dan prasarana yang dimiliki bagi pihak guru maupun siswa menjadikannya pembelajaran kurang maksimal. 


\section{SARAN}

Saran dari peneliti antara lain yaitu :

1. Pembelajaran tatap muka segera dilaksanakan agar terciptanya pembelajaran yang efektif dan tetap mematuhi protokol kesehatan yang dianjurkan oleh pemerintah.

2. Pemerintah memberikan fasilitas bantuan kuota internet untuk penunjang pembelajaran daring.

3. Guru diharapkan memberikan materi yang lebih mudah dipahami oleh siswa dan memberikan tugas dengan porsi yang sedikit.

\section{DAFTAR PUSTAKA}

Ahsani, E. L. F. (2020). "Strategi Orang Tua dalam Mengajar dan Mendidik Anak dalam Pembelajaran At The Home Masa Pandemi Covid-19". Al Athfal: Jurnral Kajian Perkembangan Anak dan Manajemen Pendidikan Usia Dini, 3(1), 37-46.

Jamaluddin, D., Ratnasih, T., Gunawan, H., \& Paujiah, E. (2020). "Pembelajaran daring masa pandemik Covid-19 pada calon guru: hambatan, solusi dan proyeksi". LP2M.

Herlina, H., \& Suherman, M. (2020). "Potensi Pembelajaran Pendidikan Jasmani Olahraga dan Kesehatan (PJOK) di Tengah Pandemi Corona Virus Disease (COVID)-19 di Sekolah Dasar". Tadulako Journal Sport Sciences And Physical Education, 8(1), 1-7. 